PP-489

insignificant cancer と款断された前立 腺痛の臨床病理像の検的

\section{国立がんセンター中央病院 泌尿器科}

川息清隆,市川宽樹,演口卓也, 佐藤 仁彦, 込山元清 岡鳥 英二郎, 松岡 直樹, 藤元 博行, 垣添 忠生

【目的】われわれは 6 本以上の検体を探取し陽性 core が $1 \sim 2$ 本、1 本中の瘦占拠率が $50 \%$ 以下、gleason score 6 以下、PSA20 以下の条件を渵たす前立腺瘤を insignificant cancer としているがこれらが真に盬床上重要でな い㾰と言えるかについて検討した。対象と方法】1988 年以降に系統的生検を行い insignificant cancer と診断 された 52 例の臨床経過を検討した。初期治療として 33 例が watchifull waiting (以下 W/W)を、17 例が手術を、 1 例がホルモン㞠法を、1 例が照射を選択した。【結果】w/ $\mathrm{w}$ 症例中PSAの上昇などを理由に再生検を受けた 11 例中 6 例は 2 度目の生検で significant cancer と診断さ れた。3 例が手術を、3例がホルモン㞠法を選択した。手 術 17 例中 8 例が non-organ confirmed disease であっ た。T2症例でも 9 症例中 4 例は病巣は微小ではなかっ た。【考察】18\%は早期にW/W から脱落し、手術症例の $71 \%$ は微小癌ではなかった。現在の生検法の限界と正確 な病態把握の困難さを示した。治療法の選択には充分な 注意が必要であり特にW/W 症例ではPSADT 等を参 考に適宜再生検を行うなどして診断を補助することが必 要と考えられた。

\section{PP-490 偶発前立腺癌の嚂床的検討}

\section{岐阜前立腺㾂研究グループ}

增栄 成泰, 小島 主太郎, 守山 洋司, 三翰 好生

後藤 高広, 演本 幸浩, 仲野 正博, 根笹 信一, 宇野裕已 柚原一哉, 出口隆

【目的】偶発前立腺癌（A1, A2）について臨床的検討を 行った。【対象】1992年1月から2001年12月までの 10 年間に当研究グループ参加 24 施設で経験したDRE 陰 性, PSA 4.0ng/ml (Tandem-R) 以下の偶発前立腺瘦 (A 1. A2) 101 例。【結果】年齡は 51 87 歳 (平均 71.2 歳)。 平均観察期間は 38 ヶ。初揨時の PSAは $0.2 \sim 4.0 \mathrm{ng}$ / $\mathrm{ml}$, 平均值は $1.67 \mathrm{ng} / \mathrm{ml}$ 。診断契機はTUR-P 95 例、被膜 下前立腺摘除術 6 例であった。臨床病期分類は A1 が 64 例、A2 が 47 例であった。診断後に何らかの治療をした 症例は $\mathrm{A} 1$ で 35 例, A2 で 32 例であり、そのうち前立腺 全摘除術を施行した症例はA1 あった。無治療例は A1 で 27 例、A2 は 5 例であった。㾰 死はA2の 1 例のみで、低分化型腺癌であった。【考察】術 前診断の精度の向上と, 偶発癌の長期予後の検討が必要 であると思われた。未集計症例を加えた結果を報告する 予定である。

\section{PP-491}

前立眿痖におけるセンチネルリンパ節 同定の跔み

金沢大学大学院 医学系研究科 集学的治療学（泌尿器 科学) "金沢大学大学院医学系研究科ハイオト レーサー診痖学 (核医学) ${ }^{2)}$

高壆 博",江川雅之", 今尾哲也",越田 潔"

並木 幹夫", 横山 邦彦

【目的】前立腺虞において Sentinel Lymph Node（SLN）を同定し Sentinel Node Navigation Surgery（SNNS）の開発を目指す。

【対象と方法】術前 N0 前立腺䆛患者を対象とした。手術開始 5 6 時間前に99m Tc 標識フチン酸を TRUSガイド下に前立腺腫瘍内に 注入した。術前 lymphoscintigraphy および術中 $\gamma$ プローブ法で SLNの同定を試みた。次にバックアップ郭清を行い摘出リンパ節 の放射能を well counter（RI 測定室）で測定した後、病理検査を 行った。

【結果】現在まで、9 例中 8 例で術前および術中にSLNを含むと考 えられる放射能の高い hot nodesを同定できた。うち 4 例で限局 郭清領域以外に hot nodes を認めた。9 例中 2 例で hot nodesにの み転移を認めた。cold nodesには転移は認めなかった。

【結論】前立腺䄽における SLN 同定には精度の高いバックアップ 郭清による検証が不可欠である。現在までの結果から前立腺癌に おいても癌の転移は SLN から生じるという Sentinel Node Concept が成立する可能性が示唆された。現在一般的に行われている 前立腺㿋に対する限局郭清領域以外にも SLN は存在すると考え られ、今後前立腺㽞に対し SNNSを行う上で留意すべき点である。

\section{$P P=492$ 前立腺癌骨転移における 1CTP の有用 性}

\section{茨城県立中央病院 泌尿器科}

遠藤 瑞木, 大谷 幹伸, 山内 敦

前立腺㾰は骨転移を起こす頻度が高く、その診断としては 現在骨シンチグラフィーが主体となっている。しかしなが ら、骨シンチグラフィーは感受性は高いが、伪陽性が多い こと、定量的評価が煩雑であること、コストが高いことな どの久点があり、近年、より簡便に測定できる骨代謝マー カーが骨転移の検索、評価に応用されつつある。そこで 我々は前立腺癌の骨転移におけるマーカーとして血中I 型コラーゲンC 末端テロペプチド（以下 1 CTP）について その骨転移検索における有用性を骨由来アルカリフォス ファターゼアイソザイム (以下骨由来 ALP) と比較・検討 した。対象】2001年1月から2002 年 7 月までの 1 年 6 ヶ月間に当科を受診し、前立腺針生検にて病理組織学的に 前立腺癌と診断され、骨シンチ等の画像検査にて骨転移を 指摘された 25 症例および骨転移を来していない 37 症例 である。【方法】骨転移症例および末転移症例につき1CTP およびに骨由来 ALP を测定し、その感度特異度について Mann-Whitney’s U testにて検定した。【結果】骨転移症例 において 1CTPと骨由来ALP との感度特異度を比較し たか、、特に有意差を認めなかった。【考察】1CTPは骨転移 の検索において骨由来ALP と同等の検査と考えられた。 